6000

Research Article

Journal of Extension Education

Vol. 30 No. 1, 2018

DOI:https://doi.org/10.26725/JEE.2018.1.30.6000-6007

\title{
An Analytical Study on Turmeric Cultivation
}

\author{
M. S. Shanthya ${ }^{1}$ and R. Premavathi ${ }^{2}$
}

\begin{abstract}
A study was undertaken to study the characteristics of turmeric farmers and to assess the relationship between characteristics of turmeric farmers and adoption level, in Kodumudi block of Erode district in Tamil Nadu. A sample of 111 respondents was selected from five villages by using proportionate random sampling method. Fifteen independent variables and one dependent variable were selected to analyze the relationship of characteristics of turmeric farmers with adoption level. The data were collected with the help of a well-structured and pre-tested interview schedule. The collected data were analyzed with suitable statistical tools. The results of the study revealed that nearly one-fourth of the respondents was having secondary school education. More than half of the respondents had farming alone as their occupation. Little more than two-fifths of the respondents were small farmers. The variables, occupation and credit orientation had positive and significant relationship with adoption at five per cent level of significance.
\end{abstract}

Keywords : Adoption; practices; regression; turmeric; Tamil Nadu

\section{INTRODUCTION}

Turmeric, known as 'Indian saffron' is an important commercial spice crop grown in India. Indian turmeric has been known to the world since ancient times. India is the largest producer, consumer and exporter of turmeric in the world. Turmeric is grown only in 6 per cent of the total area under spices and condiments in India and India is the largest producer and exporter of turmeric in the world and accounts for 78 per cent of the world's total production. Further, turmeric is the second largest foreign exchange earner among Indian spices.
In Tamil Nadu, turmeric is cultivated in about 67246 ha with production of about 368411 tons with average productivity of 5.48 t/ha. (Thiripurasundari \& Selvarani 2014). During the recent past, Tamil Nadu had witnessed sharp decline in total production due to varied weather conditions and several other constraints.

With this background, the present study entitled "An analytical study on turmeric farmers" was carried out to know the adoption level of turmeric farmers with the following objectives:

- $\quad$ To study the profile of the farmers.

1 PG Scholar \& 2 Associate Professor, Department of Agricultural Extension and Rural Sociology, Tamil Nadu Agricultural University, Coimbatore-641003

Received : 23-04-2018; Accepted : 24-05-2018 
- To analyze the relationship between characteristics of turmeric farmers and adoption level.

\section{METHODOLOGY}

The study was carried out in Erode district since the district stands first in area under turmeric in Tamil Nadu. Erode district has fourteen blocks and among them Kodumudi block was purposively selected since it had more area under turmeric cultivation. (District Directorate of Statistics, 2017). In Kodumudi block, five villages viz., Vengapur, Punjai Kollanali, Oongalur, Kollathupalayam and Kodumudi which were having maximum area in turmeric were selected for the study. A sample of one hundred eleven respondents were selected from the five villages by using proportionate random sampling method. Fifteen independent variables viz., age, educational status, occupational status, annual income, farm size, experience in turmeric cultivation, extension agency contact, social participation, mass media exposure, trainings undergone, credit orientation, economic motivation, market intelligence, awareness on post-harvest practices and ICT tool utilization behavior and adoption level of turmeric farmers as dependent variable were selected for the study. The data were collected with the help of a well-structured and pre-tested interview schedule. The collected data were analyzed with suitable statistical tools.

\section{FINDINGS AND DISCUSSION}

\section{Profile of the respondents}

The data collected on the profile of respondent farmers were analyzed and presented in Table 1.

Table 1.

Distribution of Respondents based on their Profile

$(n=111)$

\begin{tabular}{|c|l|c|c|}
\hline SI. No & \multicolumn{1}{|c|}{ Category } & Number & Percentage \\
\hline 1. & Age (in years) & 3 & 2.70 \\
\hline & Young (<35) & 22 & 18.00 \\
\hline & Middle (35-45) & 86 & 79.30 \\
\hline & Old (>45) Total & 111 & 100.00 \\
\hline & & & 13.50 \\
\hline 2. & Educational status & 15 & 13.50 \\
\hline & Illiterate & 15 & 9.00 \\
\hline & Functionally literate & 10 & 14.40 \\
\hline & Primary education & 16 & 20.70 \\
\hline & Middle education & 23 & 17.10 \\
\hline & Secondary education & 19 & 11.70 \\
\hline & Higher secondary education & 13 & 100.00 \\
\hline & Collegiate & 111 & \\
\hline & & & \\
\hline
\end{tabular}


Journal of Extension Education

\begin{tabular}{|c|c|c|c|}
\hline Sl. No & Category & Number & Percentage \\
\hline \multirow[t]{6}{*}{3.} & Occupation status & & \\
\hline & Farming alone & 62 & 55.85 \\
\hline & Farming + wage earner & 32 & 2.70 \\
\hline & Farming + Business & 3 & 28.82 \\
\hline & Farming + services & 14 & 12.61 \\
\hline & Total & 111 & 100.00 \\
\hline \multirow[t]{6}{*}{4.} & Annual income & & \\
\hline & Rs.1,00,000-2,00,000 & 89 & 80.20 \\
\hline & Rs.2,00,000-5,00,000 & 22 & 19.80 \\
\hline & Rs. $5,00,000-10,00,000$ & 0 & 0.00 \\
\hline & Rs.> 10,00,000 & 0 & 0.00 \\
\hline & Total & 111 & 100.00 \\
\hline \multirow[t]{6}{*}{5.} & Farm size & & \\
\hline & Marginal & 46 & 41.44 \\
\hline & Small & 27 & 24.32 \\
\hline & Medium & 18 & 16.21 \\
\hline & Big & 20 & 18.01 \\
\hline & Total & 111 & 100.00 \\
\hline \multirow[t]{5}{*}{6.} & $\begin{array}{l}\text { Experience in turmeric } \\
\text { cultivation }\end{array}$ & & \\
\hline & Low & 32 & 28.80 \\
\hline & Medium & 58 & 52.30 \\
\hline & High & 21 & 18.90 \\
\hline & Total & 111 & 100.00 \\
\hline \multirow[t]{5}{*}{7.} & Extension agency contact & & \\
\hline & Low & 0 & 0.00 \\
\hline & Medium & 98 & 88.30 \\
\hline & High & 13 & 11.70 \\
\hline & Total & 111 & 100.00 \\
\hline \multirow[t]{5}{*}{8.} & Social participation & & \\
\hline & Low & 6 & 5.40 \\
\hline & Medium & 90 & 81.10 \\
\hline & High & 15 & 13.50 \\
\hline & Total & 111 & 100.00 \\
\hline
\end{tabular}


An Analytical Study on Turmeric Cultivation

\begin{tabular}{|c|c|c|c|}
\hline Sl. No & Category & Number & Percentage \\
\hline \multirow[t]{5}{*}{9.} & Mass media exposure & & \\
\hline & Low & 0 & 0.00 \\
\hline & Medium & 84 & 75.70 \\
\hline & High & 27 & 24.30 \\
\hline & Total & 111 & 100.00 \\
\hline \multirow[t]{5}{*}{10.} & Trainings undergone & & \\
\hline & None & 20 & 18.01 \\
\hline & Attended one training & 47 & 42.34 \\
\hline & $\begin{array}{l}\text { Attended more than one } \\
\text { training }\end{array}$ & 44 & 39.65 \\
\hline & Total & 111 & 100.00 \\
\hline \multirow[t]{5}{*}{11.} & Credit Orientation & & \\
\hline & Low & 16 & 14.40 \\
\hline & Medium & 77 & 69.40 \\
\hline & High & 18 & 16.20 \\
\hline & Total & 111 & 100.00 \\
\hline \multirow[t]{5}{*}{12.} & Economic motivation & & \\
\hline & Low & 19 & 17.10 \\
\hline & Medium & 74 & 66.70 \\
\hline & High & 18 & 16.20 \\
\hline & Total & 111 & 100.00 \\
\hline \multirow[t]{5}{*}{13.} & Market intelligence & & \\
\hline & Low & 19 & 17.10 \\
\hline & Medium & 77 & 69.40 \\
\hline & High & 15 & 13.50 \\
\hline & Total & 111 & 100.00 \\
\hline \multirow[t]{5}{*}{14.} & $\begin{array}{l}\text { Awareness on post-harvest } \\
\text { practices }\end{array}$ & & \\
\hline & Low & 0 & 0.00 \\
\hline & Medium & 92 & 82.90 \\
\hline & High & 19 & 17.10 \\
\hline & Total & 111 & 100.00 \\
\hline
\end{tabular}




\begin{tabular}{|c|l|c|c|}
\hline SI. No & \multicolumn{1}{|c|}{ Category } & Number & Percentage \\
\hline 15. & ICT tool utilization behavior & & \\
\hline & Low & 0 & 0.00 \\
\hline & Medium & 92 & 82.90 \\
\hline & High & 19 & 17.10 \\
\hline & & 111 & 100.00 \\
\hline
\end{tabular}

It could be observed from Table 1 that majority of the turmeric farmers $(77.47 \%)$ belonged to old age category and the reason could be that most of the youngsters prefer only white collar jobs than doing farming even though they have their own lands. Nearly one-fourth of the respondents $(20.70 \%)$ were having secondary school education. Most of the villages in the study area were having education facilities upto secondary school level. This could be the possible reason for majority of the respondents having literacy upto secondary school education level. Few of the respondents would have studied in the colleges situated in nearby towns. The findings are in line with the findings of Karthika (2014) who also reported that majority of the farmers were literates in their study.

More than half $(55.85 \%)$ of the respondents had farming alone as their occupation. Majority (80.20\%) of the respondents income category was between Rs.1,00,000-2,00,000. The reason might be turmeric is one of the cash crops in the study area and also yields a good return to the farmers. Little more than two-fifths (41.44\%) of the respondents' were small farmers. The reason might be due to drought condition in the study area since two years which could have made the farmers to reduce the cultivable land area under turmeric.

More than half $(52.30 \%)$ of the respondents possessed medium level of experience in turmeric cultivation. Majority of the respondents had medium level of extension agency contact (88.3\%), social participation (81.10\%) and exposure to mass media (75.70\%) respectively. This finding is in line with the findings of Jergin (2014). The reason might be regular visits made by the extension functionaries like Assistant Agricultural Officers and Horticultural Officers, regular distribution of horticultural / agriculture literature like leaflet, folder, books etc., by the horticulture office in Kodumudi, farmers enrollment in Turmeric Farmers Association and the prevailing high literacy rate in Erode district. Less than half (42.34\%) of the respondents had attended one training on turmeric cultivation. Majority of the respondents had medium level of credit orientation (69.40\%), economic motivation (66.70\%), market intelligence (69.40\%), awareness on post-harvest practices $(82.90$ $\%)$ and ICT tool utilization behavior (82.90\%) respectively.

The reasons might be the better availability of institutional and non- 
institutional credit facilities like Co-operative banks, Nationalized banks etc., in the study area. Apart from that respondent's basic urge to earn more and their desire to improve their standard of living to clear old debts and to fulfil family commitments, medium to high level educational status, social participation and mass media exposure were some of the reasons.

\section{Association and Contribution of Respondents' Characteristics with / to Adoption level}

The relationship of selected 15 independent variables with the adoption level was studied through simple correlation and multiple regression analysis. The results have been presented in Table 2.

Table 2.

Correlation and Multiple Regression Analysis between Respondents' Characteristics and their Adoption Level

$(n=111)$

\begin{tabular}{|c|c|c|c|c|c|}
\hline SI.No & Variables & "r" Value & $\begin{array}{c}\text { Partial } \\
\text { Regression } \\
\text { Coefficient }\end{array}$ & Std Error & t Value \\
\hline$X_{1}$ & Age & -0.111 & 0.050 & 0.043 & 1.160 \\
\hline $\mathrm{X}_{2}$ & Education & $0.456^{* *}$ & 0.435 & 0.204 & $2.136^{*}$ \\
\hline $\mathrm{X}_{3}$ & Occupation & $0.192^{*}$ & -0.372 & 0.396 & -0.939 \\
\hline $\mathrm{X}_{4}$ & Annual income & $0.282^{* *}$ & 0.633 & 0.873 & 0.725 \\
\hline$X_{5}$ & Farm size & 0.069 & 0.140 & 0.278 & 0.504 \\
\hline$x_{6}$ & Experience in turmeric cultivation & -0.064 & -0.894 & 0.542 & -1.651 \\
\hline $\mathrm{X}_{7}$ & Extension agency contact & $0.410^{* *}$ & 0.153 & 0.207 & 0.738 \\
\hline $\mathrm{X}_{8}$ & Social participation & $0.464^{* *}$ & 0.304 & 0.137 & $2.214^{*}$ \\
\hline$X_{9}$ & Mass media exposure & $0.362^{* *}$ & 0.225 & 0.189 & 1.190 \\
\hline$X_{10}$ & Trainings undergone & $0.464^{* *}$ & 0.985 & 0.485 & $2.029 *$ \\
\hline$X_{11}$ & Credit orientation & $0.225^{*}$ & -0.171 & 0.276 & -0.620 \\
\hline$X_{12}$ & Economic motivation & 0.050 & 0.095 & 0.068 & 1.393 \\
\hline$X_{13}$ & Market intelligence & $0.355^{* *}$ & 0.334 & 0.171 & 1.958 \\
\hline$X_{14}$ & Awareness on post-harvest technology & 0.181 & -0.197 & 0.534 & -0.369 \\
\hline$X_{15}$ & ICT tool utilization behavior & $0.342^{* *}$ & 0.023 & 0.144 & 0.162 \\
\hline & nt at $5 \%$ level & \multicolumn{4}{|c|}{$R^{2}=0.440$} \\
\hline \multicolumn{3}{|c|}{ ** - Significant at $1 \%$ level } & $\mathrm{F}=4$. & & \\
\hline
\end{tabular}

NS - Non Significant 
From Table 2, it could be inferred that out of fifteen independent variables studied, eight variables namely, education $\left(X_{2}\right)$, annual income $\left(X_{4}\right)$, extension agency contact $\left(X_{7}\right)$, social participation $\left(X_{8}\right)$, mass media exposure $\left(X_{9}\right)$, trainings undergone $\left(X_{10}\right)$, market intelligence $\left(X_{13}\right)$ and ICT tool utilization behavior $\left(X_{15}\right)$ had shown positive and significant association with adoption at one per cent level of significance. The variables occupation $\left(X_{3}\right)$ and credit orientation $\left(X_{11}\right)$ had positive and significant relation with adoption at five per cent level of significance. The other variables did not show any relationship with adoption.

In general, higher the education level, annual income, extension agency contact, social participation, mass media exposure, trainings undergone, market intelligence and ICT tool utilization behavior, the more will be the chances for knowing, understanding and adopting the practices and hence, the variables had shown positive and significant relationship with adoption. These findings on association of extension agency contact, social participation and mass media exposure with adoption are in accordance with the findings of Shindhu (2015).

Multiple regression analysis was performed to find out the extent of contribution of each variable towards the adoption level of turmeric farmers on turmeric cultivation practices. The $\mathrm{R}^{2}$ value 0.440 revealed that 44.00 per cent of variation in the adoption level was explained by the fifteen independent variables selected for the study. The "F" value was also significant at one per cent level of significance. Hence, the results fit in the regression equation.

The prediction equation was fitted for adoption level of the respondents and is given below.

$\mathrm{Y}_{2=} 101.698+0.050\left(\mathrm{X}_{1}\right)^{\mathrm{NS}} 0.435\left(\mathrm{X}_{2}\right)^{*}-0.372$ $\left(X_{3}\right)^{N S}+0.633\left(X_{4}\right)^{N S}+0.140\left(X_{5}\right)^{N S}-0.894\left(X_{6}\right)$ NS $+0.153\left(X_{7}\right)^{\text {NS }}+0.304\left(X_{8}\right)^{*}+0.225\left(X_{9}\right)^{\text {NS }}+$ $0.985\left(X_{10}\right)^{*}-0.171\left(X_{11}\right)^{N S}+0.095\left(X_{12}\right)^{N S}+$ $0.334\left(X_{13}\right)^{N S}-0.197\left(X_{14}\right)^{N S}+0.023\left(X_{15}\right)$

It could be seen from the equation that the regression co-efficient of variables educational status $\left(X_{2}\right)$, social participation $\left(X_{8}\right)$ and trainings undergone $\left(X_{10}\right)$ were found to be positive and significant at five per cent level of probability. This suggested a unit increase in educational status $\left(X_{2}\right)$, social participation $\left(X_{8}\right)$ and trainings undergone $\left(X_{10}\right)$ would also increase adoption level of turmeric farmers on recommended turmeric cultivation practices by $0.435,0.304$ and 0.985 units respectively.

Other variables namely, age $\left(X_{1}\right)$, occupational status $\left(X_{3}\right)$, annual income $\left(X_{4}\right)$, farm size $\left(X_{5}\right)$, experience in turmeric cultivation $\left(X_{6}\right)$, extension agency contact $\left(X_{7}\right)$, mass media exposure $\left(X_{9}\right)$, credit orientation $\left(X_{11}\right)$, economic motivation $\left(X_{12}\right)$, market intelligence $\left(X_{13}\right)$ and awareness on postharvest practices $\left(X_{14}\right)$ were found as nonsignificant variables respectively.

\section{CONCLUSION}

The study revealed that the turmeric farmers differed widely in their profile. This finding stressed the importance of formulating different extension strategies for different kinds of clients by the change agency system. 
The study showed that majority of the turmeric farmers were educated and hence, literature pertinent to the modern methods of cultivation of turmeric may be provided to the farmers in order to make them in tune with the present trend in turmeric cultivation. To increase the level of adoption among the farmers, those variables that had a significant association to adoption level of turmeric farmers should be taken in to consideration while designing extension strategies. Also, by organizing result demonstrations, the farmers could be convinced to adopt all the package of practices recommended for turmeric cultivation.

\section{REFERENCES}

District Directorate of Statistics (2017), Erode
District.

Jergin, J.I. (2014). An Analytical Study on Rubber growers in Kanyakumari District of Tamil Nadu. Unpublished M.Sc (Ag) Thesis, AC\&RI, TNAU, Madurai.

Karthika, A. (2014). A Diagnostic Study on aggregate onion cultivars in Tiruppur district of Tamil Nadu. Unpublished M.Sc. (Ag.) Thesis, AC \& RI, TNAU, Madurai.

Shindhu. (2015). An analytical study on turmeric growers in erode district of Tamil Nadu. Unpublished M.Sc. (Ag.) Thesis, AC\&RI, TNAU, Madurai.

Thiripurasundari \& Selvarani. (2014). Production of Turmeric in India: An Analysis. The International Journal of Business \& Management. 2(9): 230. 